\title{
Development of Agricultural Subsector in Moving Regional Economy: An Empirical Studi in Tanah Laut Regency
}

\author{
Desy Rivina Maulita*, Hamdani and Yudi Ferrianta \\ Faculty of Agriculture, Lambung Mangkurat University, Indonesia
}

Submission: May 28, 2018, Published: July 19, 2018

"Corresponding author: Desy Rivina Maulita, Faculty of Agriculture, Lambung Mangkurat University, Indonesia, Email: desy_rivina@yahoo.co.id

\begin{abstract}
Agricultural-based economic development is one way to drive the economy in Tanah Laut Regency. This study aims to identify and analyze the agricultural subsector that can be superior in driving the economy of Tanah Laut Regency. Research location in Tanah Laut Regency with research time from November 2017 until May 2018. Analyzer used is area potential analysis by calculating Location Quotient index and Shift Share Index. The results showed that the sub-sectors having comparative advantages from Location Quotient analysis were livestock sub-sector agriculture and hunting service sub-sector, forestry sub-sector and logging and fishery sub-sector. While the sub-sectors that have competitive advantage from Shift Share analysis are fishery sub-sector, food crop sub-sector, livestock sub-sector and agriculture service sub-sector. The leading sub-sectors are the sub-sectors that have comparative and competitive advantages such as livestock sub-sector, agriculture service subsector and fishery sub-sector. Several policy recommendations were prepared as an effort to guide the performance of the leading sub-sectors and non-superior subsectors in Tanah Laut Regency.
\end{abstract}

Keywords: Economic growth; Leading subsector; Agricultural sector

Abbreviations: GRDP: Gross Regional Domestic Product; LQ: Location Quotient Analysis; SSA: Shift Share Analysis

\section{Introduction}

The objectives of economic development policies are to improve living standard, inequality reduction, and increase employment while still taking into account the resources sustainability aspects for the next generation. The success of fiscal policies reflects from economic growth which can be measured by Gross Regional Domestic Product (GRDP).

Data of BPS shows that economic growth of Indonesia during 2012-2016 was quite volatile. Economic growth was recorded at 4,88 percent in 2015 down from 6,03 percent in 2012, and less than the earlier data of 5,02 percent in 2016. Likewise, economic growth during 2012-2016 in Kalimantan Selatan Province and Tanah Laut Regency was recorded the same conditions.

Deceleration of economic growth was driven by the decrease in Mining and Quarrying Sectors. GDRP Share of mining and quarrying sector in Tanah Laut Regency was quite large, at 2530 percent. Global crisis caused the slowing down of demand for coal, as reflected in failing coal prices and declining volumes of coal trades (both of export and import). This condition impacted the coal producer country.
Poverty rate was the result of sluggish economic growth in Tanah Laut Regency. During 2013-2016, poverty rate in Tanah Laut regency was increasing, recorded at 4,33 percent (2013); 4,38 percent (2014); 4,58 percent (2015); and 4,65 percent in $2016[1,2]$.

Furthermore, this condition of economic growth caused employment percentage on agricultural sector, recorded 46,27 percent (2012); 47,36 percent (2013); 48,12 percent (2014); and 48,29 percent in 2015 [3-7]. The increments came in cause of desisting of mining sectors and employment expansion of agriculture to services.

Considering those conditions, the agricultural sector in Tanah Laut needs to be continuously developed because the percentage of poor people working in the agricultural sector is greater than those working in other sectors. By 2016, there are about 47.19 percent of the population working in the agricultural sector and 26.34 percent working in non-agricultural sector and the remaining 26.47 percent of the non-working population.

The contribution of the agricultural sector in Tanah Laut supported by the large absorption of labor should be reducing 
poverty rate and drives the regional economy. The purpose of this research is to identify and analyze the agriculture sub-sector that can be superior in driving the economy of Tanah Laut.

\section{Research Methods}

\section{Framework}

The slowdown in economic growth caused by slowing economic growth in the mining and quarrying sectors. This causes an increase in the percentage of the poor. Agricultural Sector which occupies the second position in the regional economy needs to be further improved its performance by spurring the leading subsector of agriculture.

\section{Location and time of study}

Research location in Tanah Laut Regency from November 2017 to May 2018.

\section{Method of collecting data}

The data used in this research is secondary data, namely data of ADHK GRDP Tanah Laut Regency of 2012-2016.

\section{Data analysis method}

Data Analysis Method used is the analysis of potential areas by calculating Location Quotient index and Shift Share Index as follows:

\section{Location quotient analysis (LQ)}

Use of this analysis to look at both the base and non-base subsectors, further to identify the comparative advantages of the agricultural sub-sector in Tanah Laut Regency. With the approach used is a comparison between the value of GRDP sub-sector of agriculture district with the total value of GRDP at the district level formulated mathematically as follows: region

LQij = the location coefficient index for the $\mathrm{j}^{\text {th }}$ region in the $\mathrm{i}^{\text {th }}$

$\mathrm{Xij}=\mathrm{ADHK}$ GRDP value of the $\mathrm{j}$ sub-sub-sector in Tanah Laut area

$\mathrm{Xi}=$ total ADHK GRDP in Tanah Laut Regency

$\mathrm{Xj}=$ total ADHK GRDP in the $\mathrm{j}$ sub-sector in South Kalimantan

$\mathrm{X}=$ total ADHK GRDP in South Kalimantan

With the understanding that if the sub-sector with $L Q$ value is greater than one $(L Q>1)$ then it is a base sector and has a comparative advantage, whereas if the value is equal to or less than one $(\mathrm{LQ}<1)$ means that sub-sector is not included in the base sector or not competitive.

\section{Shift-Share analysis (SSA)}

Shift share analysis (SSA) is one of many analytical techniques for understanding the shifting of activity structures in a given location compared to a (with a wider coverage area in two time points. Mathematically it can be written as follows:
Where:

$\mathrm{N}$ = National share component (Million Rupiah)

$\mathrm{P}=$ Proportional shift component (Million Rupiah)

$\mathrm{S}=$ Differential shift component (Million Rupiah)

EN= Total ADHK GRDP South Kalimantan

Er= Total ADHK GRDP Tanah Laut

$\mathrm{i}=$ sector $/$ sub-sector

$\mathrm{t}=\operatorname{year}(2016)$

$\mathrm{t}-\mathrm{n}=$ year early (2012)

Analysis methods using the previous LQ still can not show a clear picture about the economic growth of a region if not accompanied by Shift Share analysis method. By using Shift Share method, it will be able to describe the shifting of activity structure of a sub sector in Tanah Laut compared with same sub sector in South Kalimantan region.

The purpose of this analysis is to determine the performance or productivity of the working economy of Tanah Laut Regency compared with South Kalimantan Province. This analysis uses ADHK GRDP data at two different points that is in 2012 and 2016. Two points this year was chosen because starting in 2012 there is a slowdown in economic growth in the mining sector and there is a change in economic structure where the contribution of mining sector is getting smaller until the year 2016 and the contribution of agriculture sector that began to grow in the same period.

Shift Share analysis method consists of three components that have a relationship with each other, namely:

- The National Share (N) component describes the comparison of economic growth of the Tanah Laut Regency with broader regional economic growth or reference areas (South Kalimantan Province).

- $\quad$ The Proportional Shift (P) component shows the change in performance of an economic sector (field of business) in Tanah Laut Regency to the same sector in the reference area (South Kalimantan Province). Proportional shift (proportional shift) is also called the influence of industry mix (industry mix).

- $\quad$ The Differential Shift (D) component determines the extent of the industry's competitiveness capability in Tanah Laut Regency with the reference regional economy (South Kalimantan Province). Differential Shift is also called a competitive advantage.

By using this technique of analysis it can be known the main factors that affect the economic growth of a region that can come from within and outside the area concerned. External factors can be derived from the development of national and international economic activities. While factors derived from within the region 
derived from the economic structure as well as the special potential possessed by the area.

The economic growth of a region can be sustained by the sector/subsector base if the advantages and disadvantages that occur in the fulfillment process cause the mechanism of interregional import export. Or in other words, the sector/sub-sector will produce goods and services to meet the needs of domestic markets and markets outside the region. The ability to encourage economic growth of a willayah is highly dependent on the superiority or competitiveness of economic sectors/sub-sectors in the region.

In addition, to determine the strength or weakness of a sector in the region in supporting the national economy, this study also uses the Enders category which classifies the growth of the following sectors:

- A sector is given a rank of 1 if the components of industry mix and regional share are both positive then the sector is called very strong.

- A sector is ranked 2 if the positive industry mix component exceeds the negative regional share is called the strong sector.

- A sector is given a rank of 3 if the component of positive regional share exceeds the negative industry mix is called rather strong sector.

- $\quad$ A sector is given a rank of 4 if the industry mix negative component exceeds the positive regional share is called the rather weak sector.

- A sector is given a rank of 5 if the component of negative regional share exceeds the positive industry mix is called weak sector.

- A sector is given a rank of 6 if the components of industrial mix and regional share are both negative so called sector is very weak.

\section{Results and Discussion}

\section{Base sector and regional comparative advantage}

Analysis of LQ (Location Quotient) is an analysis used to measure a sector is a base sector or non base sector. The base sector will indicate that a region has a comparative advantage over other regions because it has climate advantages and land suitability, socio-economic, institutional, natural resources, human resources and marketing (Table 1).

From the results of LQ analysis in the table above, it is known that the sub-sectors that have comparative advantages are livestock sub-sector, agriculture and hunting service sub-sector, forestry sub-sector and logging and fishery sub-sector. This is because the four subsectors have $L Q$ values more than one ( $Q P>1$ ). While the other three sub-sectors, namely the food crop sub-sector, horticultural crops sub-sector and plantation sub-sector are not included as the base sector but included in the service subsector.

Table 1: Result of Analysis of LQ of Agriculture sub-sector based on ADHK GRDP Tanah Laut Year 2016.

\begin{tabular}{|c|c|}
\hline Subsector of Agriculture & $\begin{array}{c}\text { Result of } \\
\text { LQ }\end{array}$ \\
\hline$(1)$ & $(2)$ \\
\hline Agriculture, farming, Hunting \& Agricultural Services & 0,877 \\
\hline Crops & 0,928 \\
\hline Horticultural Crops & 0,491 \\
\hline Plantation crops & 0,986 \\
\hline Livestock & 1,356 \\
\hline Agricultural \& Hunting Services & 1,027 \\
\hline Forestry \& Logging & 3,005 \\
\hline 3. Fisheries & 1,105 \\
\hline
\end{tabular}

Source: Data processed, 2017

\section{Regional competitive advantages}

Table 2: Result of Analysis Shift Share Subsector of Agriculture based on ADHK GRDP Tanah Laut Year 2016.

\begin{tabular}{|c|c|c|c|c|c|}
\hline Subsector of Agriculture & & & & & Enders Category \\
\hline (1) & (2) & (3) & (4) & (5) & (6) \\
\hline $\begin{array}{l}\text { 1. Agriculture, farming, Hunting \& Agricultural } \\
\text { Services }\end{array}$ & $190.212,82$ & $-59.051,56$ & $-74.963,03$ & $56.198,23$ & 6 \\
\hline a. Crops & $73.647,84$ & $-19.099,12$ & $13.436,20$ & $67.984,92$ & 3 \\
\hline b. Horticultural Crops & $1.268,19$ & $-394,34$ & $-68,32$ & 805,53 & 6 \\
\hline c. Plantation crops & $82.222,91$ & $-36.889,09$ & $-135.658,63$ & $-90.324,82$ & 6 \\
\hline d. Livestock & $28.876,02$ & $-827,69$ & $21.026,44$ & $49.074,77$ & 3 \\
\hline e. Agricultural \& Hunting Services & $4.197,86$ & $-217,64$ & $3.137,52$ & $7.117,73$ & 3 \\
\hline 2. Forestry \& Logging & $34.445,18$ & $-39.407,92$ & $-2.132,26$ & $-7.095,00$ & 6 \\
\hline 3. Fisheries & $69.195,02$ & $5.325,33$ & $-26.149,60$ & $48.370,74$ & 2 \\
\hline
\end{tabular}

Source: Data processed, 2017 
By using Shift Share method it will be able to describe the shifting of activity structure of a sub sector in Tanah Laut Regency compared with same sub sector in South Kalimantan Province. The purpose of this analysis is to determine the performance or productivity of the working economy of Tanah Laut Regency compared with South Kalimantan Province. This analysis uses ADHK GRDP data at two different points that is in 2012 and 2016. Two points this year was chosen because starting in 2012 there is a slowdown in economic growth in the mining sector and there is a change in economic structure where the contribution of mining

\section{Identification and analysis of featured sub-sectors}

Table 3: Result Analysis of LQ and Shift Share Subsector of Agriculture based on ADHK GRDP Tanah Laut Year 2016.

\begin{tabular}{|c|c|c|}
\hline Subsector of Agriculture & Result of LQ Analysis & Shift Share Analysis Results \\
\hline-1 & -2 & -3 \\
\hline 1. Agriculture, farming, Hunting \& Agricultural Services & Non Base & Very weak \\
\hline a. Crops & Non Base & Rather strong \\
\hline b. Horticultural Crops & Non Base & Very weak \\
\hline c. Plantation crops & Non Base & Very weak \\
\hline d. Livestock & Base & Rather strong \\
\hline e. Agricultural \& Hunting Services & Base & Rather strong \\
\hline 2. Forestry \& Logging & Base & Very weak \\
\hline 3. Fisheries & Base & Strong \\
\hline
\end{tabular}

Source: Data processed, 2017

The leading subsector is a sub-sector that can be further developed and aims to improve the economic growth of a region. A subsector is said to be superior if the subsector has advantages either comparatively or competitively. From the result of LQ analysis and Shift Share before, got result as shown in Table 3.

From the table above, there are three subsectors that passed the test on LQ and Shift Share analysis, namely livestock subsector, agriculture service sub-sector and fishery sub-sector. It is this superior sub-sector that will be boosted in the short term (1-5 years) to improve the welfare of farmers and ultimately reduce poverty. While the sub-sectors are not superior does not mean will be ignored just like that. In the short term (1-5 years) will be identified causes of problems that occur in the sub-sector and will be sought solution. So that in the medium and long term (over 5 years), the sub-sector can spur its performance and become the leading subsector in Tanah Laut.

The food crop sub-sector has a large contribution in GRDP but its economic growth is unstable. In addition to the effects of weather and climate, the nature of the community, which is largely subsistence farmers, causes rice production to be limited to meet domestic demand alone. The same is true of the horticulture subsector. Society considers only business in the food crops and horticulture sub-sectors and selects other business fields that are more quick yielding (such as traders, laborers, etc.).

Plantation subsector originally in 2012 is a contributor in the formation of PDRB continues to decline, ie from 28.98 percent in 2012 continues to decline until the number 22.70 percent in 2016. sector is getting smaller until the year 2016 and the contribution of agriculture sector that began to grow in the same period.

Based on Enders category, only fishery sub-sector is included in rank 2 is a strong category. While the food crops sub-sector, livestock sub-sector and agriculture service sub-sector are included in rank 3 ie the sub-sector category is rather strong. While the other three sub-sectors are horticultural sub-sector, estate sub-sector and forestry sub-sector are included in very weak sub-category and included in rank 6 (Table 2).
The decline in prices of rubber and oil palm seems to be one cause of the decline in production.

Forestry sub-sector though passes on LQ analysis and become the base subsector, but in Shift Share analysis turns out to be in very weak sub-sector. This is because during the last 5 years, the production of forestry commodity subsector continues to decline. This phenomenon is seen from the downward trend of economic growth in the forest subsector in Tanah Laut from 0.86 percent successively slowed from 2012 to 2016 [8-13].

Subsectors excluding pre-eminent seeds can thrive and contribute to regional development if supported by adequate infrastructure. Therefore, policies in the economic development of the Tanah Laut area should consider infrastructure and capacity, land carrying capacity, human resources, market opportunities and other natural factors.

\section{Conclusion and Recommendations}

\section{Conclusion}

From the result of area potential analysis, that is LQ analysis and Shift Share analysis, got result that fishery sub-sector is leading sub-sector. Followed by subsector of farming and agricultural services and hunting. While the subsectors of food crops, horticulture, plantations and forestry are not included in the leading subsector.

Recommendations that can be proposed to local governments include:

\section{Recomendation}


1. Improved performance of the leading sub-sectors in the fisheries, livestock, agricultural and hunting services subsectors, carried out by the following steps:

a. Provision of subsidies. The subsidy can be subsidized by input prices and output prices.

b. Assistance in the provision of ships and fishing gear which are leased exclusively to fishermen who do not have large ships and adequate fishing gear. This is because the poor live mostly in coastal areas with jobs as fishermen.

c. Promotion of the insurance program also needs to be reviewed and implemented. With the insurance it can protect the production and can reduce the losses of farmers.

d. The government can also collaborate with the industrial sector, so that output from agriculture can be an input to the industrial sector. The same is done in the subsector of farming and agricultural services and hunting.

2. Performance subsector not leading subsector, ie food crops, horticulture, plantation and forestry sub-sector, so that in the medium and long term (above 5 years), the subsector can become the leading sub-sector in Tanah Laut, which can be done by:

a. Application of "resi gudang" system.

b. Implementation of agricultural insurance.

c. There is a need for easy access to sales by collaborating with the manufacturing sector. As far as possible the processing industry companies in Tanah Laut prioritize domestic inputs.

3. There needs to be ongoing training and coaching for farmers to add skills and insight into the use of agricultural tools, modern agricultural technology and the latest farming methods. In addition, there is a need for easy access of farmers to get the help of agricultural credit with low interest and ease of guarantee/collateral. For the wide varieties of farmed land, farmers are given insights on how to cultivate intercropping or planting twice a year using superior seeds. It aims to increase agricultural production capacity.

\section{References}

1. BPS, Laut T (2017) PDRB Kabupaten Tanah Laut Menurut Lapangan Usaha Tahun 2014-2016. Pelaihari: BPS Kabupaten Tanah Laut.

2. BPS, Laut T (2016) PDRB Kabupaten Tanah Laut Menurut Lapangan Usaha Tahun 2013-2015. Pelaihari: BPS Kabupaten Tanah Laut.

3. BPS (2012) Labor Force Situation in South Kalimantan August 2012. Jakarta: Central Bureau of Statistics of South Kalimantan Province, Indonesia.

4. BPS (2013) Labor Force Situation in South Kalimantan August 2013 Jakarta: Central Bureau of Statistics of South Kalimantan Province, Indonesia.

5. BPS (2014) Labor Force Situation in South Kalimantan August 2014. Jakarta: Central Bureau of Statistics of South Kalimantan Province, Indonesia.

6. BPS (2015) Labor Force Situation in South Kalimantan August 2015. Jakarta: Central Bureau of Statistics of South Kalimantan Province, Indonesia.

7. BPS, Laut $T$ (2015) PDRB Kabupaten Tanah Laut Menurut Lapangan Usaha Tahun 2010-2014. Pelaihari: BPS Kabupaten Tanah Laut.

8. BPS (2010) Table of Labor Force Situation in South Kalimantan August 2001-2009. Social Security Section of Social Statistics BPS of South Kalimantan Province, Indonesia.

9. BPS (2011) Labour Force Situation in South Kalimantan August 2011. Jakarta: Central Bureau of Statistics of South Kalimantan Province, Indonesia.

10. Lutfi F (2006) Dinamika Pembangunan Pertanian dan Pedesaan. Banjabaru: Pustaka Banua.

11. Kusumawati (2012) Analisis Ekonomi Basis dan Komponen Pertumbuhan Sektor Pertanian di Kabupaten Jepara. Jurnal Agribisnis Fakultas Pertanian. Surakarta: Sebelas Maret University, Indonesia.

12. Josmun N (2010) Analisis Pengembangan Subsektor Tanaman Pangan dan Hortikultura dalam Penanggulangan Kemiskinan di Kabupaten Halmahera Barat Provinsi Maluku Utara (Tesis). IPPWP. Bogor: Institut Pertanian.

13. Simatupang P (2000) Kelayakan Pertanian Sebagai Sektor Andalan Pembangunan Ekonomi Nasional. Bogor: Pusat Penelitian Sosial Ekonomi Pertanian.

Your next submission with Juniper Publishers
will reach you the below assets
- Quality Editorial service
- Swift Peer Review
- Reprints availability
- E-prints Service
- Manuscript Podcast for convenient understanding
- Global attainment for your research
- Manuscript accessibility in different formats
( Pdf, E-pub, Full Text, Audio)
- Unceasing customer service
Track the below URL for one-step submission
https://juniperpublishers.com/online-submission.php

